Jurnal SEMAR Vol. 10 No. 1 , hal. $1-6$

elSSN: 2745-4223 | Copyright @ LPPM Universitas Sebelas Maret Homepage: https://jurnal.uns.ac.id/jurnal-semar

\title{
Pelatihan Membuat Game Menggunakan Software Construct 2 untuk Meningkatkan Motivasi Belajar pada Siswa SMK
}

\author{
Suliswaningsih*1, Chyntia Raras Ajeng Widiawati ${ }^{2}$, Alif Yahya Syafa'at ${ }^{3}$, Bela Tyara Nur Fajrina ${ }^{4}$ \\ 1,3,4 Informatika, ${ }^{2}$ Teknologi Informasi, Fakultas Ilmu Komputer, Universitas Amikom Purwokerto \\ *suliswani@amikompurwokerto.ac.id
}

\begin{abstract}
Abstrak
Bermain game secara berlebihan dapat menimbulkan dampak yang merugikan. Salah satu dampak negatif yang dapat ditimbulkan dari bahaya kecanduan game adalah dari segi waktu yang dapat mempengaruhi motivasi dan prestasi belajar siswa. Waktu luang yang seharusnya digunakan untuk mendalami materi pelajaran sekolah justru dihabiskan untuk menyelesaikan level demi level dalam permainan video game. Siswa Sekolah Menengah Kejuruan merupakan salah satu pengguna permainan (games), baik laki-laki maupun siswa perempuan. Usia siswa dapat diarahkan pada kegiatan yang lebih produktif. Ketertarikan para siswa dalam bermain game dapat dimanfaatkan sebagai motivasi dalam belajar. Sehingga siswa tidak hanya sebagai pengguna tetapi dapat diarahkan untuk membuat game secara mandiri. Namun sebagian besar jurusan di SMK merupakan jurusan yang tidak berorientasi pada profesi programmer, sehingga siswa belum memiliki pengetahuan tentang pemrograman game. Hal ini tentu menjadi permasalahan bagi siswa untuk membuat game secara mandiri. Tujuan pengabdian ini adalah memberikan pelatihan membuat game pilah sampah organik dan sampah anorganik tanpa coding menggunakan perangkat lunak Construct 2. Adapun metode pelaksanaannya antara lain dilakukan observasi untuk menganalisis kebutuhan mitra, permasalahan mitra, perancangan serta penawaran solusi, pelaksanaan kegiatan utama, hingga tahap pelaporan kegiatan. Hasil dari pelatihan adalah pengetahuan dan pemahaman tentang logika dasar pemrograman game dalam bentuk permainan pilah sampah organik dan anorganik berbasis android.
\end{abstract}

Kata kunci-pelatihan, game, construct 2

\section{Pendahuluan}

Game adalah suatu cara untuk menghilangkan kepenatan dengan melakukan suatu kegiatan yang dilalui dengan menggunakan kecerdasan berpikir dan strategi yang harus digunakan untuk berinteraksi dengan sistem dan konflik yang direkayasa secara sengaja untuk menimbulkan keseruan dalam bermain. Sedangkan game mobile adalah game yang dijalankan di ponsel berfitur, smartphone/tablet, smartwatch, PDA dan media player portable(Sandy \& Hidayat, n.d.). Game mobile pada dasarnya memberikan banyak manfaat bagi penggunanya. Namun sayangnya, saat ini banyak orang yang telah menjadi pecandu berat game, khususnya anak-anak dan remaja.

Bermain game secara berlebihan dapat menimbulkan dampak yang merugikan. Salah satu dampak negatif yang dapat ditimbulkan dari bahaya kecanduan game adalah dari segi waktu yang dapat mempengaruhi motivasi dan prestasi belajar anak. Waktu luang yang seharusnya digunakan untuk mendalami materi pelajaran sekolah justru 
dihabiskan untuk menyelesaikan level demi level dalam permainan video game. Hal ini akan berdampak buruk bagi daya konsentrasi konsentrasi mereka dan kesulitan menyerap materi pelajaran yang diberikan oleh guru secara maksimal(Ariantoro, 2016).

Menurut Surbakti (2017), dalam penelitiannya yang berjudul "Pengaruh Game Online terhadap Remaja" menyimpulkan bahwa game online mempunyai dampak dampak positif dan dampak negatif bagi remaja. Dampak positif dapat dirasakan manakala pemain dapat menggunakan game dengan bijak, contohnya hanya sebatas untuk menghilangkan kepenatan dalam pekerjaan. Namun sebaliknya, game juga dapat berdampak negatif jika game sudah memberikan efek kecanduan bagi pemain, khususnya dari segi waktu, uang, kesehatan, psikologi, sosial dan bagi pelajar akan dapat mempengaruhi semangat belajar. (Surbakti, 2017)

Menurut Pho dan Dinscore (2015) dalam peneletiannya, menyimpulkan bahwa "Game Based Learning dapat digunakan dalam berbagai cara untuk meningkatkan pengajaran perpustakaan, dan penelitian lintas disiplin mendukung keefektifannya di kelas. Jika dirancang dengan mempertimbangkan prinsip-prinsip pembelajaran, game dapat meningkatkan motivasi, keterlibatan, dan pembelajaran siswa". (Pho \& Dinscore, 2015)

Pelajar SMK merupakan salah satu pengguna permainan (games), baik laki-laki maupun pelajar perempuan. Pada perkembangannya banyak sekali jenis game yang dapat dimainkan. Namun dalam hal ini game mobile masih mendominasi dan diminati oleh banyak kalangan terutama pelajar sekolah menengah. Hal itu dikarenakan hampir mayoritas pelajar SMA dan atau SMK di Indonesia adalah pengguna smartphone. Selain itu, game berbasis mobile mudah di-install secara gratis melalui fitur Google Playstore. Keasyikan bermain game tak jarang membuat orang tua beranggapan bahwa game menimbulkan dampak negatif dan mempengaruhi minat belajar bagi pelajar.

Usia pelajar dapat diarahkan pada kegiatan yang lebih produktif. Ketertarikan para pelajar dalam bermain game dapat dimanfaatkan sebagai motivasi dalam belajar. Sehingga pelajar tidak hanya sebagai pengguna tetapi dapat diarahkan untuk membuat sebuah game secara mandiri.

Kebutuhan bidang pekerjaan baru berimplikasi pada keahlian dan kemampuan calon pekerja dalam mempersiapkan diri menghadapi tantang kebutuhan dunia kerja. Saat ini kebutuhan dunia industri khususnya di bidang pengembangan game berbasis mobile memiliki prospek yang menjanjikan. Sehingga diperlukan penyesuain kompetensi bagi siswa SMK sebagai calon pengembang game mobile perlu mendapat perhatian khusus, sebagai contoh dengan mengadakan seminar dan pelatihan terkait pengembangan game berbasis mobile. (W. N. Hidayat, Patmanthara, Setiani, Sutikno, \& Sutadji, 2020)

Menurut Hidayat dan Komariah (2017), dalam penelitiannya yang berjudul "Pengukuran Tingkat Pengenalan Pengguna Games Terhadap Muatan Budaya Indonesia Pada Mobile Game Berbasis Android (Studi Kasus: Dakon, Karapan Sapi dan Temple Rush Prambanan)", menyimpulkan bahwa game dapat meningkatkan pengenalan muatan budaya Indonesia melalui game Dakon Temple Rush: Prambanan dan Karapan Sapi) dan pengembang game tersebut merupakan para pengembang game lokal. (D. Hidayat \& Komariah, 2017) Sehingga produktifitas siswa SMK dapat diarahkan sebagai salah satu pengembang game, khususnya game lokal.

Berdasarkan permasalahan di atas, maka dilakukan pengabdian dalam bentuk pelatihan. Kegiatan yang dilakukan yaitu memberikan pelatihan membuat game sederhana menggunakan software Construct 2 untuk siswa SMK. Siswa SMK tersebut merupakan para siswa yang sedang melaksanakan Praktek Kerja Lapangan di Universitas Amikom Purwokerto. Siswa PKL berasal dari beberapa SMK di Kabupaten Banyumas, Purbalingga dan Cilacap. Pemilihan siswa PKL sebagai mitra yaitu terkait alasan banyaknya waktu luang yang hanya dimanfaatkan oleh para siswa untuk sekedar duduk dan bermain smartphone. Oleh karena itu pelatihan membuat game menggunakan software Construct 2 dapat menjadi ilmu pengetahuan tambahan bagi para siswa PKL disamping pengalaman kerja di lapangan. Setelah mengikuti pelatihan diharapkan siswa PKL memiliki keterampilan tambahan tentang pembuatan game, sehingga mereka tidak hanya sebagai pengguna tetapi sebagai pengembang game mobile.

Salah satu dampak positif video game yaitu menigkatkan kemampuan dan motivasi belajar. Kompleksitas dari video game memberikan kesempatan untuk meningkatkan keterampilan kognitif dan penalarannya. Video game 
telah berkembang ke titik dimana pengguna harus mangambil kendali dan berpikir strategi, memecahkan teka teki, sabar dan kreatif agar mereka dapat melanjutkan ke babak permainan berikutnya(Ridoi, 2018).

Untuk mengembangkan game yang bagus, maka diperlukan pengetahuan tentang pemrograman dan penguasaan bahasa pemrograman. Namun tidak semua orang (khususnya siswa SMK) dapat memahami pemrograman dengan mudah. Pemrograman masih dianggap sebagai ilmu yang sulit untuk dipahami oleh siswa SMK, karena di dalam pemrograman terdapat banyak perintah dalam bahasa asing (Inggris). (Irawan, Prasetio, Wibowo, \& Pranoto, 2015)

Membangun sebuah game setidaknya harus menguasai yaitu kemampuan dasar pemrograman game. Namun pada kenyataannya, pemrograman masih dianggap ilmu yang cukup sulit untuk dikuasai, khususnya oleh siswa SMK. Pada materi pemrograman terdapat banyak sekali perintah yang harus dipelajari, sehingga para siswa merasa pesimis mampu membuat permainan (game) secara mandiri.

Construct 2 adalah salah satu aplikasi pembuatan permainan yang sederhana dan dapat dimainkan pada sistem operasi Windows 8, android. Construct 2 tidak menggunakan bahasa pemrograman khusus, karena semua perintah yang digunakan pada game diatur dalam EvenSheet yang terdiri dari Event dan Action. Game yang dihasilkan dapat juga di-publish pada Google Playstore. Sehingga game yang dihasilkan dapat bernilai jual dan memberikan keuntungan, serta dapat membuka peluang usaha khususnya bagi siswa yang setelah lulus sekolah tidak mampu melanjutkan ke jenjang pendidikan tinggi.

\section{Metode Pelaksanaan}

Pelatihan dilaksanakan di Laboratorium Komputer Universitas Amikom Purwokerto. Karena selama masa pandemic, maka pelatihan dibagi menjadi 2 pertemuan yaitu kelompok pertama pada tanggal 16 September 2020 dan kelompok kedua pada tanggal 17 September 2020. Peserta adalah siswa SMK yang sedang malekasanakan Praktik Kerja Lapangan di Universitas Amikom Purwokerto yaitu sebanyak 20 siswa. Siswa PKL berasal dari beberapa SMK di Kabupaten Banyumas, Purbalingga dan Cilacap. Pemilihan siswa PKL sebagai mitra yaitu terkait alasan banyaknya waktu luang yang hanya dimanfaatkan oleh para siswa untuk sekedar duduk dan bermain smartphone.

Berdasarkan permasalahan tersebut, maka solusi yang ditawarkan adalah pengabdian dalam bentuk pelatihan membuat game 2D pilah sampah organik dan sampah anorganik. Adapun tahapan proses pelaksanaannya antara lain :

1. Tahap analisis kebutuhan mitra dalam bentuk pre test. Pre test digunakan untuk mengetahui tingkat pengetahuan dan pemahaman siswa sebelum mengikuti pelatihan. Pada tahap ini siswa diberi link google form yang berisi kuisioner tentang seberapa tahu mereka tentang game dan perangkat lunak untuk membuat game.

2. Tahap penyampaian materi pelatihan dilakukan dengan 2 metode yaitu teori dan praktikum. Pada tahap ini materi yang disampaikan pada kelas teori adalah mengenai perkembangan game pada revolusi industri 4.0 dan logika dasar pemrogaman game. Selanjutnya adalah praktikum membuat game pilah sampah organik dan sampah anorganik menggunakan software Construct 2. Materi praktik meliputi instalasi dan pengenalan Construct 2, pembuatan game pilah sampah organic dan sampah anorganik, dan cara export game ke perangkat mobile.

3. Tahap evaluasi pelatihan dalam bentuk post test untuk mengetahui tingkat pengetahuan dan pemahaman siswa setelah mengikuti pelatihan. Hasil kuesioner pre test dan post test yang terkumpul digunakan untuk mengevaluasi perubahan tingkat pengetahuan dan pemahaman peserta sebelum dan sesudah mengikuti pelatihan.

Tim pengabdian memberikan materi teori pada 30 menit di awal dan 2,5 jam berikutnya digunakan untuk praktik membuat sampai dengan export game ke perangkat mobile. Teori dilakukan dalam bentuk ceramah dan presentasi oleh pembicara, disertai dengan diskusi dan tanya jawab terkait materi yang disampaikan. 
Metode teori dan praktik yang digunakan dalam pelatihan bertujuan untuk membuat peserta tidak jenuh dengan materi yang disampaikan, sedangkan praktik membuat game menggunakan perangkat lunak Construct 2 dapat memberikan pemahaman bagi siswa untuk mengimplementasikan teori yang sudah diberikan. Saptiono dalam Sutikno, mendefinisikan pembelajaran sebagai seperangkat tindakan yang disusun dalam mendukung proses belajar peserta didik, dengan memperhitungkan kejadian-kejadian eksternal yang mempengaruhi kejadian-kejadian internal dalam diri peserta didik (Sutikno, 2013). Saptiono (dalam Daft, 2011), menyatakan bahwa pelatihan dan pengembangan dilakukan dengan tujuan memfasilitasi peserta pelatihan dalam mempelajari pengetahuan dan keterampilan agar memiliki pengalaman terkait hal yang dipelajari(Daft, 2011).

\section{Hasil Dan Pembahasan}

Kegiatan pengabdian kepada masyarakat yang dilakukan pada masa pandemic harus tetap memperhatikan protokol kesehatan yaitu PSBB, mengenakan masker dan menjaga jarak aman. Oleh karena itu, pengabdian dilakukan selama 2 hari dengan pembagian menjadi 2 kelompok masing-masing berjumlah maksimal 10 orang. Masingmasing sesi/pertemuan terdiri dari 2 tahap, yaitu; tahap penyampaian teori mengenai logika dasar pemrogaman game menggunakan perangkat Construct 2 dan tahap implementasi teori dalam bentuk praktikum langsung pengoperasian Construct 2 pada pembuatan game pilah sampah organik dan sampah anorganik di Laboratorium Universitas Amikom Purwokerto.

Pada awal pelatihan, peserta diberikan kuisioner pre test melalui link google form terkait tema pengabdian. Pre test dilakukan untuk mengukur tingkat pengetahuan peserta sebelum diberi materi mengenai pembuatan game. Selanjutnya tim pengabdian memberikan materi terkait pembuatan game dan diselingi dengan sesi diskusi dan tanya jawab. Lalu dilanjutkan dengan praktik instalasi Construct 2 dan dilanjutkan dengan praktik membuat game pilah sampah organik dan sampah anorganik menggunakan Construct 2 dengan didampingi oleh 2 asisten praktikum.

Selama proses pelatihan tidak ada kendala yang berarti. Sebagian besar peserta merasa antusias dan rasa ingin tahu yang besar. Walaupun ada beberapa peserta yang terkendala dalam pencarian fitur pada menu Construct 2. Namun hal itu terjadi karena peserta belum terbiasa mengoperasikan perangkat lunak Construct 2. Hal itu dapat segera diatasi dengan adanya pendampingan dari asisten prakikum yang segera memberikan arahan tentang cara pengoperasian yang benar.

Pada akhir sesi pelatihan yang dilakukan selama 3 jam pada setiap pertemuan, sebagian peserta berhasil menyelesaikan pembuatan game sampai proses export pada perangkat mobile. Namun, terdapat beberap peserta yang masih belum sampai ke tahap export game. Hal ini wajar karena faktor pemahaman beserta yang berbedabeda. Tetapi secara keseluruhan pelatihan berjalan sesuai rencana.

Selain itu, melalui pelatihan ini, dilakukan pula pengamatan terhadap peserta selama praktik pembuatan game menggunakan Construct 2 yang dilakukan pada tanggal 16-17 September 2020 di Laboratorium Komputer Universitas Amikom Purwokerto. Berdasarkan pengamatan tersebut, para peserta pelatihan terlihat antusias dan dapat melakukan praktik pembuatan game dengan baik.

Gambar 1 adalah dokumentasi yang menunjukkan kegiatan peserta selama melakukan praktik membuat game pilah sampah organik dan sampah anorganik di Laboratorium Komputer 4 Universitas Amikom Purwokerto. Peserta dapat mengoperasikan dan menggunakan fitur-fitur yang ada pada perangkat lunak Construct 2 dengan baik sambil mendengarkan arahan dari pembicara. 


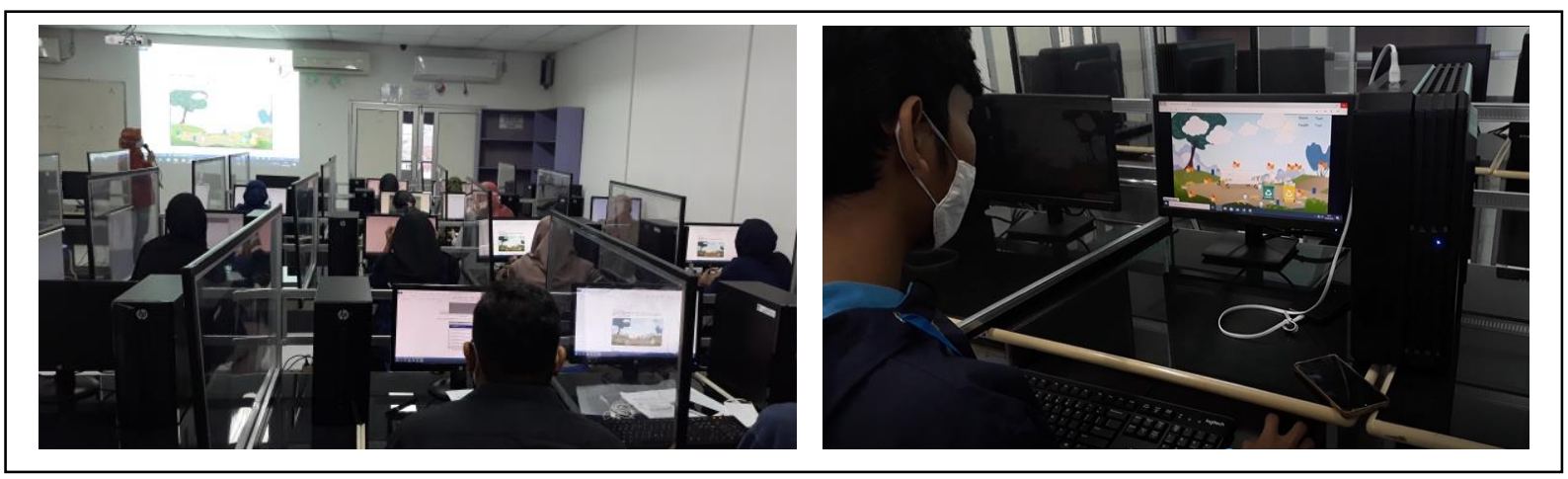

Gambar 1 Pelatihan membuat game menggunakan Construct 2

\section{Kesimpulan}

Berdasarkan hasil dan pembahasan pengabdian kepada masyarakat, maka dapat disimpulkan beberapa hal sebagai berikut:

1. Pengabdian kepada masyarakat dalam bentuk pelatihan membuat game menggunakan perangkat lunak Construct 2, dengan jumlah peserta sebanyak 20 orang yang berasal dari beberapa SMK di Kabupaten Banyumas dan Purbalingga. Peserta telah mendapatkan pelatihan membuat game pilah sampah organik dan sampah anorganik. Pelatihan memberikan pengetahuan, pemahaman dan keterampilan dalam membuat game, khususnya game 2D. Hampir seluruh peserta yang awalnya menganggap pembuatan game sulit dan harus memiliki kemampuan pemrograman, mengalami peningkatan baik pengetahuan, maupun rasa percaya diri dan antusiasme yang tinggi untuk tidak hanya sekedar bermain game, tetapi dapat membuat game secara mandiri.

2. Berdasarkan hasil pelatihan membuat game menggunakan perangkat lunak Construct 2 pada tanggal 16-17 September 2020, peserta pelatihan mengalami peningkatan pengetahuan dan pemahaman tentang logika dasar pembuatan game 2D. Pelatihan tersebut sekaligus mematahkan anggapan para peserta bahwa membuat game itu sulit dan identik dengan coding yang rumit. Akan tetapi, pengabdian kepada masyarakat akan lebih efektif apabila dilakukan secara berkelanjutan dan cakupan yang lebih luas. Sehingga manfaat pengabdian dapat dirasakan oleh masyarakat luas.

\section{Ucapan Terima Kasih}

Ucapan terima kasih kepada Lembaga Penelitian dan Pengabdian kepada Masyarakat (LPPM) Universitas Amikom Purwokerto yang telah mendanai sehingga kegiatan Amikom Mitra Masyarakat ini dapat berjalan dengan lancer. Terima kasih khususnya kepada siswa-siswa SMK dari Kabupaten Cilacap, Banyumas dan Purbalingga yang telah berpartisipasi aktif sebagai peserta dalam kegiatan pelatihan ini. 


\section{Daftar Pustaka}

Ariantoro, T. R. (2016). Dampak Game Online Terhadap Prestasi Belajar Pelajar. JUTIM (Jurnal Teknik Informatika Musirawas, 1(1), 45-50. https://doi.org/https://doi.org/10.32767/jutim.v1i1.22

Daft, R. L. (2011). Era Baru Manajemen (New Era of Management). Penerjemah Tita Maria Kanita, Jakarta: Salemba Empat.

Hidayat, D., \& Komariah, S. H. (2017). Games Terhadap Muatan Budaya Indonesia Pada Mobile Game Berbasis Android ( Studi Kasus : Dakon, Karapan Sapi Dan Temple the Measurement of Game Users Recognition Levels Toward Indonesian Culture on Android-Based Mobile Game (Case Study : Dakon ,. 4, 31-36.

Hidayat, W. N., Patmanthara, S., Setiani, A., Sutikno, T. A., \& Sutadji, E. (2020). Pelatihan Pengembangan Mobile Game Edukasi untuk Guru SMK Bidang Teknologi Komputer dan Informatika Kota Malang. Jurnal Karinov, 3(1). Retrieved from http://journal2.um.ac.id/index.php/jki/article/view/11991/5108

Irawan, J. D., Prasetio, S., Wibowo, S. A., \& Pranoto, Y. A. (2015). Pelatihan Pembuatan Game Menggunakan Greefoot. Industri Inovatif, 5(2), 29-35. Retrieved from http://eprints.itn.ac.id/id/eprint/3427

Pho, A., \& Dinscore, A. (2015). Game-based Learning. Association of College and Research Libraries and American Library Association.

Ridoi, M. (2018). Cara Mudah Membuat Game Edukasi dengan Construct 2. Maskha.

Sandy, T. A., \& Hidayat, W. N. (n.d.). Konsep Game Mobile Learning. Retrieved from https://books.google.co.id/books?hl=id\&lr=\&id=ICePDwAAQBAJ\&oi=fnd\&pg=PA72\&dq=pemrograman+g ame+mobile+adalah\&ots=MpqvlAPwqS\&sig=YeP6WvTTiw276zwWkxwtTay8E_0\&redir_esc=y\#v=onepag $\mathrm{e} \& \mathrm{q}=$ pemrograman game mobile adalah $\& \mathrm{f}=\mathrm{false}$

Surbakti, K. (2017). Pengaruh Game Online Terhadap Remaja. Jurnal Curere $\mid$ Vol. $01 \mid$ No. $01 \mid$ April 2017|pISSN : 2597-9507| e-ISSN: 2597-9515,01(01), 28-38. Retrieved from

http://www.portaluniversitasquality.ac.id5388ojssystemindex.phpcurerearticleview2022

Sutikno, S. (2013). Belajar dan Pembelajaran. Lombok: Holistica, 49-50. 